Transpacific Imaginations 



\section{Transpacific Imaginations}

History, Literature, Counterpoetics

\section{Yunte Huang}

HARVARD UNIVERSITY PRESS

Cambridge, Massachusetts

London, England

2008 
Copyright @ 2008 by the President and Fellows of Harvard College All rights reserved

Printed in the United States of America

Library of Congress Cataloging-in-Publication Data

Huang, Yunte.

Transpacific imaginations : history, literature, counterpoetics / Yunte Huang.

p. $\mathrm{cm}$

Includes bibliographical references and index.

ISBN-13: 978-0-674-02637-7 (alk. paper)

ISBN-10: 0-674-02637-3 (alk. paper)

1. American literature-Asian influences. 2. American literature-19th century-History and criticism. 3. American literature-20th centuryHistory and criticism. 4. American literature-Asian American authorsHistory and criticism. 5. Pacific Area-In literature. I. Title.

PS159.A85H83 2007

$810.9^{\prime} 325-\mathrm{dc} 22 \quad 2007020027$ 
For Isabelle Huang and Ira Huang 
